\title{
Article/Artigo
}

\section{Evaluation of pathogenic fungi occurrence in traumatogenic structures of freshwater fish}

\author{
Avaliação da ocorrência de fungos patogênicos em estruturas traumatogênicas de peixes \\ fluviais
}

\section{Fabio Caetano Oliveira Leme ${ }^{1}$, Marcos Mendes de Barros Negreiros ${ }^{1}$, Fernando Akira Koga ${ }^{1}$, Sandra de Moraes Gimenes Bosco' ${ }^{2}$ Eduardo Bagagli ${ }^{2}$ and Vidal Haddad Junior ${ }^{1}$}

\begin{abstract}
Introduction: Fungal infections in human skin, such as sporotrichosis, can occur after fish induced trauma. This work aimed to identify fungi in freshwater fish that are pathogenic to humans. Methods: Extraction of dental arches from Serrassalmus maculatus (piranha) and Hoplias malabaricus (wolf fish), stings from Pimelodus maculatus (mandis catfish), dorsal fin rays from Plagioscion spp. (corvina) and Tilapia spp., for culture in Mycosel agar. Some cultures were submitted to DNA extraction for molecular identification by sequencing ITS-5.8S rDNA. Results: Cultures identified most yeast as Candida spp., while sequencing also permitted the identification of Phoma spp. and Yarrowia lipolytica. Conclusions: While the search for S. schenckii was negative, the presence of fungus of the genera Phoma and Candida revealed the pathogenic potential of this infection route. The genus Phoma is involved in certain forms of phaeohyphomycosis, a subcutaneous mycosis caused by dematiaceous fungi, with reports of infections in human organs and systems. Traumatizing structures of some freshwater fish present pathogenic fungi and this may be an important infection route that must be considered in some regions of Brazil, since there are a large number of a fisherman in constant contact with traumatogenic fish.
\end{abstract}

Keywords: Freshwater fish. Pathogenic fungi. Phoma. Human mycosis. Candida spp. Fishermen.

\section{RESUMO}

Introdução: Infecções fúngicas na pele humana (como a esporotricose) podem se manifestar após traumatismos por peixes. O objetivo deste trabalho é procurar fungos patogênicos para o homem em peixes fluviais. Métodos: Extração de arcadas dentárias Serrassalmus maculatus (piranha) e Hoplias malabaricus (traíra), ferrões de Pimelodus maculatus (mandis), raios da nadadeira dorsal de Plagioscion spp. (corvina) e Tilapia spp. para a realização do cultivo em agar Mycosel. Algumas culturas foram submetidas à extração de DNA para a identificação molecular pelo seqüenciamento da região ITS-5.8S do rDNA. Resultados: As culturas mostraram que a maioria das leveduras era Candida spp. e o sequenciamento também permitiu a identificação de Phoma spp. e Yarrowia lipolytica. Conclusões: Embora a pesquisa para S. schenckii tenha sido negativa, a presença de fungos do gênero Phoma e Candida revela o potencial patogênico desta via de infecção. O gênero Phoma está envolvido em alguns casos de feohifomicoses, micoses subcutâneas causadas por fungos dematiáceos com relatos de infecções em órgãos e sistemas humanos. As estruturas traumatizantes de alguns peixes fluviais apresentam fungos patogênicos e esta pode ser uma importante via de infecção que deve ser considerada em algumas regiões do Brasil, uma vez que há um grande número de pescadores e peixes traumatogênicos.

Palavras-chaves: Peixes fluviais. Fungos patogênicos. Phoma. Micoses humanas. Candida spp. Pescadores.

1. Departamento de Dermatologia e Radioterapia, Faculdade de Medicina de Botucatu, Universidade Estadual Paulista, Botucatu, SP. 2. Departamento de Microbiologia e Imunologia, Instituto de Biociências, Universidade Estadual Paulista, Botucatu, SP.

Address to: Dr. Vidal Haddad Junior. Dept ${ }^{\circ}$ Dermatologia e Radioterapia/FMB/UNESP. Caixa Postal 557, 18618-970 Botucatu, SP, Brasil.

Phone/Fax: 5514 3882-4922

e-mail: haddadjr@fmb.unesp.br

Received in 14/09/2010

Accepted in 24/11/2010

\section{INTRODUCTION}

Fungi are ubiquitous and are found in soil, water, vegetables, animals and in humans. Fungal species undergo changes in incidence and according to location, season and air moisture content, as well as other variables ${ }^{1}$. The growth of fungi can be divided into two phases, vegetative and reproductive. Most of these microorganisms are made up of microscopic filaments with welldefined cell walls called hyphae. Fungi were classified as plants until 1969 and then inserted into a separate kingdom called Fungi. In fact, they are phylogenetically more closely related to animals than plants and some of them are responsible for infections in several tissues. Sporothrix schenckii is an example of a fungus causing infections in humans; it causes subcutaneous mycosis with acute or chronic evolution. Fungi are installed by previous injuries, such as scratches by sharp plant or animal structures ${ }^{2,3}$. There are well documented infections transmitted by dog bites ${ }^{4}$, rats $^{5}$ and other animals. Sporotrichosis has also been documented from handling fish, originally reported by Mayorga \& Caceres in $1978^{6}$ and more recently in Brazil ${ }^{7,8}$. The incidence of accidents in river fishermen appears to be high, as observed in retrospective and prospective studies 9 . Poor working conditions and a lack of preventive measures are precipitating factors and the main fish species causing accidents are of commercial value and present traumatic structures or are venomous, such as mandis catfish, tilapia, traíras, piranhas and others. A large number of injuries and envenomings result in secondary fungal and bacterial infections that require further study to develop improved treatment and preventive measures against these accidents in fishing communities ${ }^{10}$. The objectives of this communication were to research the possible presence of pathogenic fungi in common fish present in the nets of fluvial fishermen. 


\section{METHODS}

Considering the cases of sporotrichosis reported by one of the authors ${ }^{7,8}$, this work aimed to verify the existence of S. schenkii and other potentially pathogenic fungi in traumatogenic structures (stings, rays of fins and sharp teeth) of fish cited as the most hazardous by local fishermen and documented as such in previous publications?. The methods were applied in the same river where the cases of sporotrichosis were previously identified, in the Piracicaba River, near the Tietê River, in the central region of the State of São Paulo, Brazil. In three samples collected on three mornings of daily routine work of the colony of fishermen, two specimens each of corvina or freshwater silver croaker (Plagioscion squamosissimus), piranha (Serrasalmus maculatus), dog-fish (Acestrothychus lacustris), mandijuba or mandiamarelo catfish (Pimelodus maculatus), tilapia (Tilapia spp.) and wolf fish (Hoplias malabaricus) were obtained.

A sterile scalpel blade was used to remove traumatic structures from each fish, which were then directly inoculated into culture medium: upper and lower dental arches from Acestrothychus lacustris, Hoplias malabaricus and Serrassalmus maculatus; dorsal fin rays from Plagioscion squamosissimus and Tilapia spp. and stingers from
Pimelodus maculatus (Figure 1). These steps were conducted where the fish were captured, at the fishermen's colony on the Piracicaba River, close to the junction with the Tietê River.

The cultures were duplicated and incubated at $25^{\circ} \mathrm{C}$ and $35^{\circ} \mathrm{C}$. Cultures at $25^{\circ} \mathrm{C}$, close to ambient temperature, were used to investigate fungal flora and assess possible changes in fungi morphology. Cultures at $35^{\circ} \mathrm{C}$ were intended to investigate the possible presence of fungal pathogens, because this is closer to human body temperature and pathogenic fungi, such as S. schenckii, show increased tolerance to heat.

The yeasts were isolated in the samples and maintained in Sabouraud Dextrose Agar (SDA) with subcultures every 15 days. During the final period, the yeasts were cultivated on CHROMagarCandida (CHROMagar-Candida, Difco ${ }^{\mathrm{TM}}$ ), a differential culture medium for identifying Candida albicans, Candida tropicalis, and Candida spp., by respectively developing green, blue, and pink colonies $^{10}$. The CHROMagar-Candida plates were divided and, following colony cultivation, were incubated up to $25^{\circ} \mathrm{C}$ for a maximum of five days to observe staining ${ }^{10}$.

Ethical considerations

The study was approved by Botucatu Medical School Animal Research Ethics Committee.

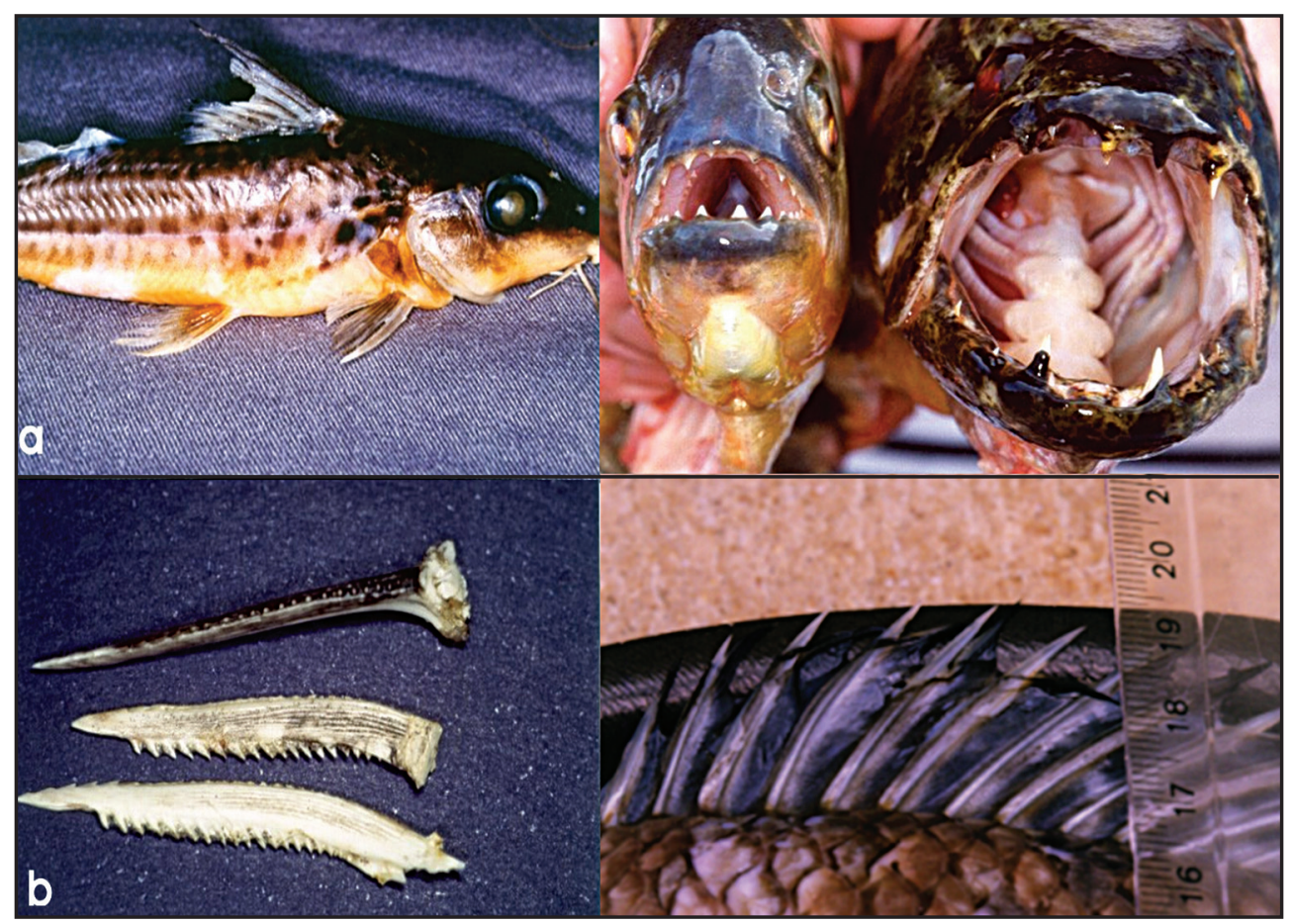

FIGURE 1 - Left, a and b: mandis and stings (Pimelodus maculatus). Right, top: teeth from piranha (Serrassalumus maculatus) and traíra (Hoplias malabaricus). Right, below: fin rays of Tilapia spp.

\section{RESULTS}

Figure 2 is a macroscopic view of the isolated colonies. Evaluation by CHORMagar ${ }^{\mathrm{TM}}$ enabled most of the yeasts to be classified. One isolate obtained from Tilapia was classified as C. tropicalis (blue color; Figure 2).

DNA extraction permitted high concentrations to be obtained, making it necessary to dilute samples for use in PCR reactions. The PCR reactions were all successful, demonstrating amplicons of approximately 400-650bp, as shown in Figure 3. These amplicons were purified and subjected to gene sequencing analysis to obtain the nucleotide sequence to compare with NCBI genomic databases (National Center for Biotechnology Information) using BLAST (Basic Local Alignment Search Tool for nucleotide).

Nucleotide sequence analyses presented consistency with fungi of the genus Phoma spp. and Yarrowia lipolytica, the latter is used in genetic engineering experiments and is currently reported as nonpathogenic, while the former is a pathogenic fungus associated with diseases in various organs and human systems, primarily the skin. Phoma belongs to the group of phaeohyphomycosis ${ }^{11-14}$. 


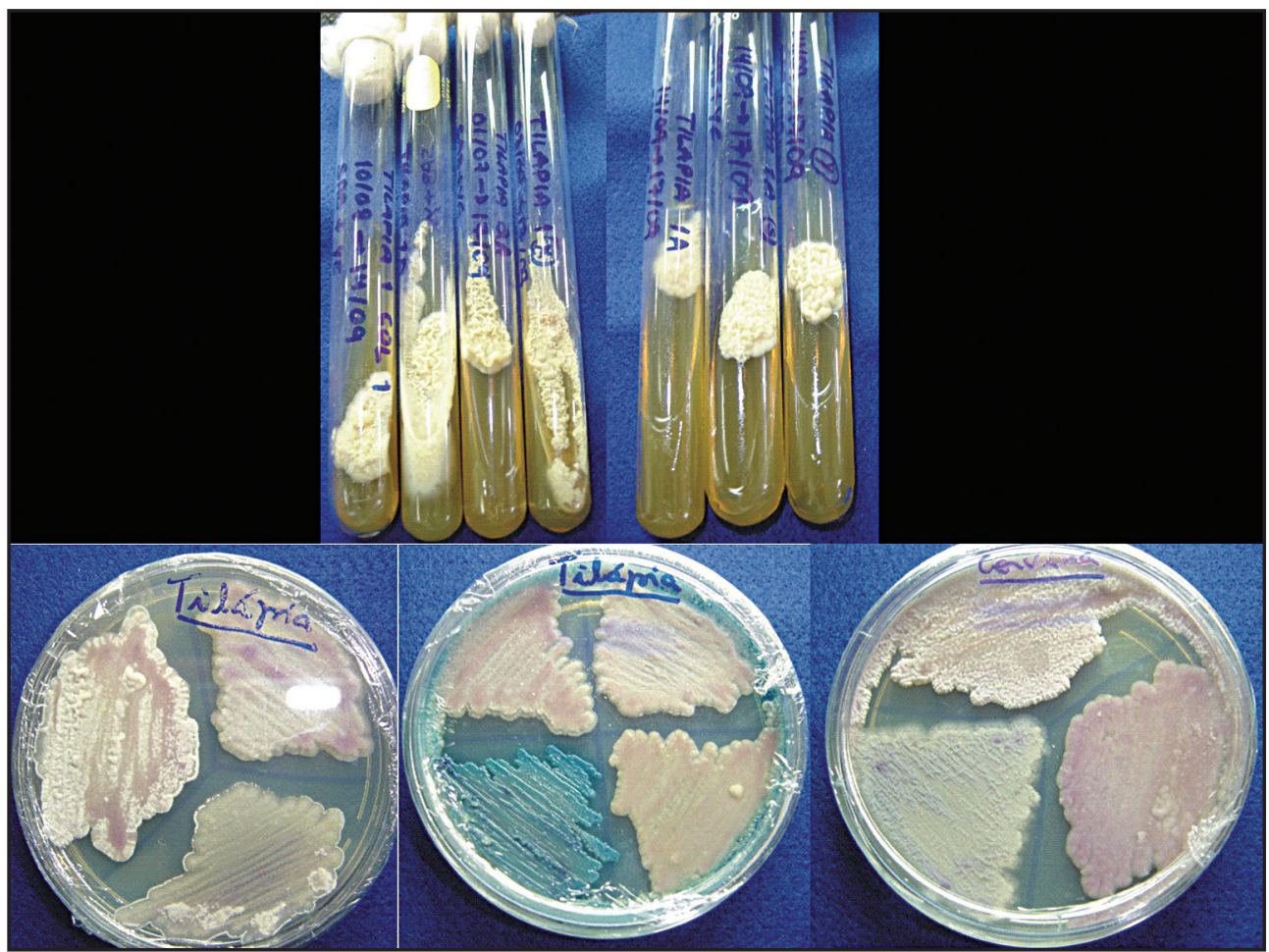

FIGURE 2 - Macroscopic view of yeast isolates on SDA agar at $25^{\circ} \mathrm{C}$. Analysis of the color acquired in $\mathrm{CHROMagar-}$ Candida ${ }^{\mathrm{TM}}$ in yeast isolates grown at $25^{\circ} \mathrm{C}$ for five days.

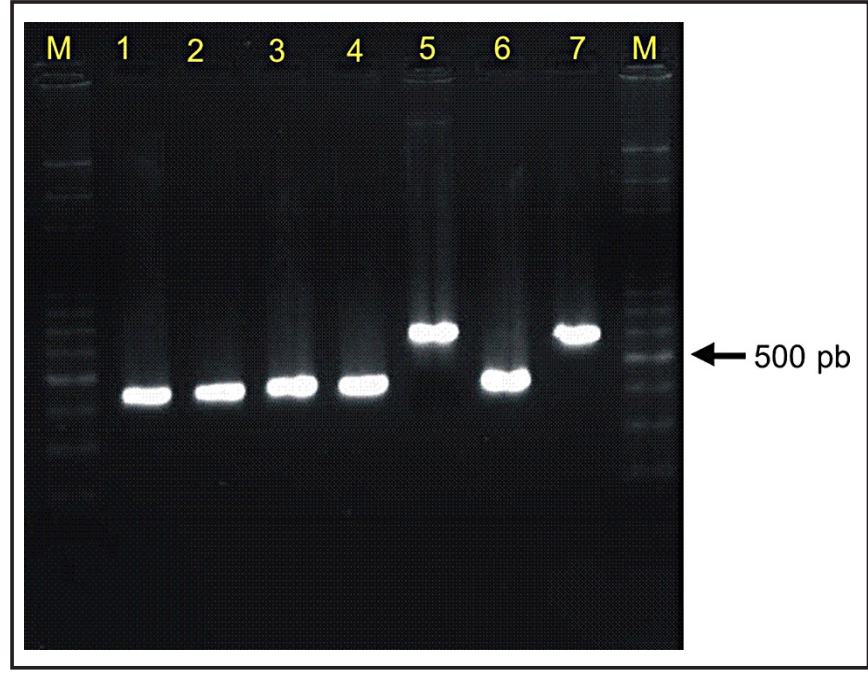

FIGURE 3 - PCR reaction for yeast isolates.

1: colony A from Mandi catfish number 1, 2: colony 2 from Mandi catfish number 2, 3: colony B from Mandi catfish number 2, 4: colony A from Corvina 1, 5: colony S from Corvina 1, 6: colony B from Corvina 1, 7: colony X from Corvina 1, M: 100bp Marker (LGC Biotechnology)

\section{DISCUSSION}

Due the fact that this research was original, certain difficulties were experienced when identifying the fungi, even with positive cultures from various yeasts and the inclusion of CHORMagar-Candida to analyze the colonies, the molecular methods were very important steps in helping to identify the microorganisms. While the association between sporotrichosis and trauma caused by fish has strong supporting evidence ${ }^{7-9}$, the search for $S$. schenkii was unsuccessfully. However, the identification of fungi of the Phoma genus reveals the pathogenic potential of this infection route: this microorganism is still poorly known in medical circles, even though several reports exists of human illness associated with this fungus ${ }^{11-14}$, especially when iatrogenic states or immunosuppression is also present, or pathological states, such as AIDS and heterologous transplants.

In conclusion, the traumatic structures of certain river fish contain Candida yeasts and DNA extraction, PCR reactions and ribosomal region DNA sequencing revealed the presence of fungus of the Phoma genus and the species Yarrowia lipolytica. Further studies are required to improve current understand of these and other fungi, especially when considering the large number of fishermen and potentially traumatogenic fish in Brazil.

\section{CONFLICT OF INTEREST}

The authors declare that there is no conflict of interest.

\section{FINANCIAL SUPPORT}

Fábio Caetano Oliveira Leme and Marcos M. de B. Negreiros were awarded scientific initiation grants, PIBIC/CNPq (Scientific initiation scholarship recipient).

\section{REFERENCES}

1. Lacaz CS. Tratado de Micologia Médica. $9^{a}$ ed. São Paulo: Editora Sarvier; 2002 .

2. Powell KE, Taylor A. Cutaneous sporotrichosis in forestry workers. Epidemic due to contaminated sphagnum moss. JAMA 1978; 240:232-235.

3. Kenyon EM, Rusel LH, McMurray DN. Isolation of Sporothrix schenckii from potting soil. Mycopathologia 1984; 87:128.

4. Rippon JW. Medical Mycology. $3^{\text {th }}$ ed. Philadelphia: W.B. Saunders; 1988.

5. Millington FR, Leite EV. Esporotricose humana provavelmente transmitida por mordedura de rato. Rev Bras Clin Ter 1941; 10:389-394. 
6. Mayorga R, Caceres A. Étude d'une zone d'endemie sporotrichosique au Guatemala. Sabouraudia 1978; 76:185-198.

7. Haddad Jr V, Miot HA, Bartoli LD, Cardoso AC, Camargo RMP. Localized lymphatic sporotrichosis after fish-induced injury (Tilapia sp.). Med Mycol 2002; 40:425-427.

8. Haddad Jr V. Infecções cutâneas e acidentes por animais traumatizantes e venenosos ocorridos em aquários comerciais e domésticos no Brasil: descrição de 18 casos e revisão do tema. An Bras Dermatol 2004; 79:157-167.

9. Haddad JrV. Animais aquáticos potencialmente perigosos do Brasil: Guia Médico e Biológico. São Paulo: Editora Roca; 2008.

10. Beighton D, Ludford R, Clark DT, Brailsford SR, Pankhurst CL, Tinsley GF et al. Use of CHROMagar Candida medium for isolation of yeasts from dental samples. J Clin Microbiol 1995; 33:3025-3027.

11. Gordon MA, Salkin IF, Stone WB. Phoma (Peyronellaea) as zoopathogen. Sabouraudia 1975; 13:329-333.

12. Baker JG, Salkin IF, Forgacs P, Haines JH, Kemma ME. First report of subcutaneous phaeohyphomycosis of the foot caused by Phoma minutella. J Clin Microbiol 1987; 25:2395-2397.

13. Hirsch AH, Schiff TA. Subcutaneous phaeohyphomycosis caused by an unusual pathogen: Phoma species. J Am Acad Dermatol 1996; 34:679-680.

14. Everett JE, Busick NP, Sielaff T, Wahoff DC, Dunn DL. A Deeply Invasive Phoma Species Infection in a Renal Transplant Recipient. Transplantation Proc 2003; 35:1387-1389. 